\title{
El desierto en la literatura chilena. Una mirada ecocrítica ${ }^{1}$
}

\author{
Mauricio Ostria González \\ Universidad de Concepción \\ mostria@udec.cl
}

\begin{abstract}
"Experimentó de nuevo la angustiosa sensación de que el suyo era un trabajo sin tiempo. En las tardes la pampa le golpeaba el cerebro. . le parecía que su amo real era el desierto omnipotente..."

V. Teitelboim

"... aquello no era un camino sino un mar inmóvil, erizado de crestas de sal. Sorteando como un poseído el encrespado oleaje, duro siniestro, agobiador, recorrió muchos kilómetros..."
\end{abstract}

L. González Zenteno

"Al pie de este sol: semillería de piedras, colores que envenenan, muerte. jHe aqui la fotografía de la pampa chilena! Y, sin embargo, allí ha sido-y es- la vida el acento dominador. Vida que fue menester traer con el agua y el coraje, venciendo a la puna y a la sed, al acaso y al desengaño"

A. Sabella

El desierto ha sido un territorio largamente explotado, no solo económicamente, sino como recurso literario y artístico, porque se ha estimado propicio para imaginar situaciones límite de carácter dramático, tanto en la esfera de las experiencias personales como en contextos históricos, filosóficos o religiosos. Desde la Biblia y el Corán hasta Merton, Sarmiento, Quiroga, Borges y Rulfo; desde San Juan de la Cruz y los místicos hasta O. Paz y R. Zurita; desde las Mily una noches y Pedro Solís y Valenzuela ${ }^{2}$ hasta Bolaño y Rivera Letelier, hablar del desierto ha supuesto siem-

1 Este texto es parte del proyecto FONDECYT 1170385, "Los espacios heterogéneos del Norte Grande en las literaturas y prácticas escénicas", actualmente en ejecución, del que el autor es investigador responsable y co-investigadora la Dra. Patricia Henríquez. Un artículo semejante, pero fuertemente orientado a la literatura del Norte Grande, fue publicado en Anales de Literatura Chilena 30 (2018): 171-181, en un dossier dedicado a estudios de ecocrítica.

2 Probablemente, el primer novelista hispanoamericano en construir una visión del desierto, en su El desierto prodigioso y el prodigio del desierto. 
pre, construir diversas imágenes y escenarios simbólicos que pueden representar desde el vacío absoluto hasta la tortuosa habitación infernal; desde la aventura hazañosa hasta la codicia implacable; desde el lugar propicio para la purificación y el éxtasis espiritual hasta el habitat amado en su desolada ternura; desde el lugar sin límites donde todo es posible hasta aquel donde la imaginación o la enajenación se pierden en espejismos y fantasmagorías ilusorias o indicios de otros modos de existencia; desde la posibilidad de comunicación con el cosmos hasta la consideración de la adusta pequeñez de la piedra o el grano de arena.

El desierto es, pues, uno de esos signos, imágenes, territorios configuradores de mundos complejos y, por eso mismo, posible de ser entendido, imaginado, padecido o exaltado desde las más diversas perspectivas y encontrados sentires. En suma, el desierto se yergue, desde siempre, en la imaginación humana como la representación de lo absoluto, lo infinito, degradado o sublime, lo otro inconmensurable y, al mismo tiempo, como la posibilidad de la destrucción total y la nada, el poder ominoso por excelencia, o la oportunidad de salvación por el despojo total y el advenimiento del dominio de sí en la generosidad y en la unidad con lo absoluto.

Por otra parte, históricamente, en el contexto del imperialismo europeo y el auge del positivismo, los desiertos 'debían' ser colonizados, apropiados y cartografiados. Es decir, pensar el desierto implicaba necesariamente la urgencia de vaciarlo y transformarlo, mediante la apropiación nominal y simbólica, en un no-desierto. Las representaciones simbólicas del desierto aparecerán, en este caso, acompañando el proceso político de expansión territorial, gestando un sentido común respecto del espacio, una mentalidad acerca de sus temas, un horizonte espacial, colectivo (León 1999). Por eso, en el pensamiento latinoamericano del siglo XIX y comienzos del XX, el desierto es considerado como espacio de lo bárbaro que hay que domesticar.

\section{2}

La gran mayoría de los ecosistemas terrestres se halla en procesos de degradación por efecto de la acción humana. El fenómeno se manifiesta como crisis de la biodiversidad (extinción de especies), como cambio climático o calentamiento global, como desertificación. Incluso, y aunque parezca paradójico, también los espacios desérticos están expuestos a las mismas amenazas. Es el caso del Norte Grande chileno, donde su máxima fragilidad, las condiciones climáticas extremas y los más de 10.000 años de ocupación humana, no obstante sus condiciones inhóspitas, han provocado un deterioro creciente de su ya de por sí difícil equilibrio ambiental. Por ejemplo, en los últimos cien años, el desierto ha padecido los efectos de la demanda generada por las nuevas ciudades, las oficinas salitreras y los centros mineros, demanda expresada en la reducción de los salares en las zonas altas, la 
contaminación y uso indiscriminado de acuíferos; la regresión de vegas y bofedales en los valles y zonas ribereñas de la precordillera; la reducción de especies arbóreas y arbustos nativos, empleados, especialmente, en faenas mineras, de construcción y turismo. A ello debe sumarse la contaminación por la creciente presencia de relaves y desechos tóxicos, residuos mineros, derrames de metales pesados, por las emisiones de centrales termoeléctricas, basurales, destrucción de zonas arqueológicas, el abandono de tierras, actividades agrícolas y la consecuente emigración del habitante nativo hacia los enclaves mineros y centros urbanos.

A pesar de constituir un extraordinario reservorio de riquezas mineras y de energías renovables, un maravilloso lugar para la observación astronómica, un inigualable museo de presencias ancestrales, así como un espacio heterogéneo de insospechadas y originales culturas que se expresan en historias, dramas, cantos y danzas, artesanías, pinturas y construcciones de sus hombres y mujeres, casi siempre ignorados, el Norte (identificado con el desierto) ha devenido en la otredad de Chile, imagen negativa, caracterizada por la extrema aridez, las temperaturas infernales, en suma, el dominio de la muerte. Así, el Norte ha sido articulado como una representación simbólica opuesta a las bondades del resto del país ("copia feliz del Edén"). En efecto, tras la idea del Norte = desierto, como forma de representación simbólica, se oculta un sistema de preferencias, de inclusiones y exclusiones equivalente a lo infernal, equiparable a la selva en La vorágine, el páramo de la novela rulfiana, El lugar sin límites de Donoso o la Santa Teresa, de Bolaño: un complejo simbólico que incluye, junto con el espacio injustamente demonizado, la manera personal o social de vivir en el mundo de la gente que allí habita o trabaja.

Pero el Norte Grande no es solo desierto. Está compuesto, longitudinalmente, por tres grandes espacios geográficos de muy distinta condición, que dispuestos de oeste a este son: la costa y la cordillera que lleva su nombre, la depresión intermedia o pampa y el macizo andino. El río Loa, atraviesa estas formaciones, transportando recursos hídricos desde la cordillera andina hasta el océano Pacífico. Cada uno de esos espacios enmarca culturas diversas, heterogéneas, aunque relacionadas desde sus orígenes: la de la precordillera andina, enraizada en las culturas agrarias indígenas, pero fuertemente intervenida por los procesos de la gran minería del cobre, ahora también del litio; por la actividad turística y la investigación astronómica; la del desierto, en el que surge y se desarrolla la efímera cultura pampina, vinculada en todos sus aspectos a las faenas extractoras del nitrato; y la de la costa en que antaño se asentaron las antiguas culturas chinchorro y chango y ahora se yerguen ciudades portuarias y caletas de pescadores, centradas casi siempre en actividades comerciales y de servicios. Aunque los tres rostros espaciales del Norte Grande se relacionan entre sí, sus vínculos son complejos y no tan estrechos como para impedir procesos culturales diferentes y hasta opuestos. En este medio geográfico, 
laboral y cultural heterogéneo interactúan gentes oriundas de muy diferentes lugares, etnias y culturas. Allí se mezclan, entrecruzan e invaden perfiles económicos, sociales y culturales muy disímiles, que se conjuntan para producir una historia compleja, contradictoria y agónica: a los pueblos aborígenes se unen chilenos de todos los rincones del país, peruanos, bolivianos, argentinos del noroeste, croatas, árabes y chinos, ingleses, estadounidenses, italianos, alemanes, españoles, etc., convocados principalmente por las riquezas mineras y salitreras, quienes terminaron configurando una identidad cultural compleja, ciertamente heterogénea, no siempre fácil de caracterizar.

\section{3}

Sea por las dificultades sin cuenta que impone el desierto a la vida humana, o por el riesgo permanente que convierte la vida en aventura precaria; tal vez por la paradoja de la riqueza encerrada en la más absoluta aridez o por los conflictos personales y sociales que surgieron de la apetencia desmesurada; quizá por las nostalgias que el paisaje polvoriento desataba en los enganchados o en los fantasmas que poblaban la imaginación afiebrada de los tercos buscadores de tesoros; lo cierto es que la literatura nortina, especialmente su narrativa, se identificó prontamente con el desierto y el hombre del norte fue visto casi siempre como una emanación de ese universo de seca apariencia, pero de rico mundo interior. El desierto convertido en territorio es la pampa.

Desde el principio, desde los cronistas de la conquista y la colonia, el desierto fue visto como un espacio inhabitado, hostil a toda forma de vida, cuya fuerza telúrica se ejerce trágicamente con quienes se atreven a adentrarse en él. Las primeras alusiones al infamado despoblado de Atacama se hallan en los cronistas del siglo XVI. Ya entonces, el territorio es señalado como reino de la sequedad y de la muerte. Así, lo describe el historiador colonial, Pedro Mariño de Lobera:

. . largo despoblado cuya travesía es de ciento y veinte leguas, donde [los españoles] pasaron trabajos excesivos, por ser muy estéril y sin género de hierba ni agua ni otro pasto para los caballos. .. son tan ásperos y fríos los vientos de los más lugares deste despoblado, que acontece arrimarse al caminante a una peña y quedarse helado y yerto en pie por muchos años, que parece estar vivo. . pocas aguas que fuera de la lluvia hay en estos desiertos son tan inútiles que, o están en jagüeyes a doce y trece leguas, o en algunos pocos manantiales donde corren clarísimas acequias de agua que convidan tanto con su transparencia, que se abalanzan a ella los que llegan sedientos, conociendo por experiencia cuánta verdad será que el deleite tiene la apariencia amena, dejando al gusto amargo más que acíbar. Ni es menos inútil el agua de un hermoso río deste despoblado, que siendo tan grata al aspecto como la pasada, apenas se 
ha tomado en la mano, cuando está vuelta en sal cuajada, de la cual solo son sus riberas sin otra cosa (249-250).

\section{4}

En la poesía chilena moderna, los dos ganadores del Premio Nobel, Gabriela Mistral y Pablo Neruda, se refieren al desierto acentuando sus aspectos negativos. ${ }^{3}$ Dice Mistral:

Cierto lugar del mundo recibió como destino una costra terrestre despojada de toda gracia vegetal y de toda ternura de agua. . . Su color es de un pardo blanquecino y desabrido cuando no es una reverberación de sol. Su aire se reseca tanto que rompe la roca o el caliche en cascajos. . Toda ella parece el engendro de un acuafortista calenturiento (378-379).

Pero es en la poesía de Neruda, cuyo eje imaginario material es el agua, ${ }^{4}$ donde se da con mayor evidencia, la visión negativa del desierto. 5 En efecto, sus características geográficas constituyen un universo semántico absolutamente opuesto al que configuran los bosques lluviosos del sur de Chile. De manera que en la imaginación nerudiana, raigalmente identificada con el territorio de la lluvia,6 el desierto es lo ajeno, lo otro, la alteridad indescifrable, el antipaisaje, el vacío absoluto, el espacio infinito, el infierno y la muerte. Así evoca Neruda, su experiencia límite frente al desierto: "En pocos sitios del mundo la vida es tan dura y al par tan desprovista de todo halago para vivirla. Cuesta indecibles sacrificios transportar el agua, conservar una planta que dé la flor más humilde, criar un perro, un conejo, un cerdo". Y continúa:

Yo procedo del otro extremo de la república. Nací en tierras verdes, de grandes arboledas selváticas. Tuve una infancia de lluvia y nieve. El hecho solo de enfrentarme a aquel desierto lunar significaba un vuelco en mi existencia ... La tierra desnuda, sin una sola hierba, sin una gota de agua, es un secreto inmenso y huraño. Bajo los bosques, junto a los ríos, todo le habla al ser hu-

3 Cf. mi artículo "Visión nerudiana del desierto nortino" (2004).

4 Véase Ostria González 2012.

5 Véase Ostria González 2004.

6 "Así mi cuerpo fue extendiéndose, de noche / mis brazos eran nieve, / mis pies el territorio huracanado, / y crecí como un río al aguacero, / y fui fértil con todo / lo que caía en mí, germinaciones / cantos entre hoja y hoja, escarabajos / que procreaban, nuevas / raíces que ascendieron / al rocío / tormentas que aún sacuden / las torres del laurel, el racimo escarlata / del avellano, la paciencia / sagrada del alerce, / y así mi adolescencia / fue territorio, tuve / islas, silencio, monte, crecimiento , / luz volcánica, barro de caminos, /humo salvaje de palos quemados" (41-42). 
CARTOGRAFíAS E IMAGINARIOS DE LA LITERATURA CHILENA: ESPACIOS, TEMPORALIDADES Y SUJETOS

mano. El desierto, en cambio, es incomunicativo. Yo no entendía su idioma, es decir, su silencio (Confieso que he vivido 191).

El texto esboza un sistema de oposiciones diametrales en el que el polo positivo lo constituye el sur verde y lluvioso, donde la vida es fácil y deleitosa y 'donde todo le habla al ser humano'; mientras, el negativo es el norte desértico, en que la vida es dura, 'desprovista de todo halago' e indescifrable. Enfrentarse a ese 'secreto inmenso y huraño’ significa reconocer su radical alteridad. La escritura nerudiana construye, entonces, un sistema semántico, dominado por connotaciones negativas, frente al cual el sujeto reconoce su diferencia y se distancia. Entonces, habla de 'esas tierras'. Los siguientes versos representan, elocuentemente, la visión negativa y ominosa del desierto:

Voz insufrible, diseminada

sal substituida

ceniza, ramo negro

en cuyo extremo aljófar aparece la luna

ciega, por corredores enlutados de cobre.

Qué material, que cisne hueco

hunde en la arena su desnudo agónico

y endurece su luz líquida y lenta?

Qué rayo duro rompe su esmeralda

entre sus piedras indomables hasta

cuajar la sal perdida? (Canto General 394)

Otras veces, en largos versos que lo prefiguran, el desierto aparece como un cielo al revés, donde los minerales asumen la figura de flores infernales y 'negras ramas':

Más allá de los pies del alcatraz, cuando

agua ni pan ni sombra tocan la dura etapa,

el ejercicio del salitre asoma

o la estatua del cobre decide su estatura.

Es todo como estrellas enterradas, como puntas amargas, como infernales

flores blancas, nevadas de la luz temblorosa

o verde y negra rama de esplendores pesados (396) 
El movimiento de aproximación y hasta de identificación con el desierto se vincula al sentimiento de solidaridad del poeta con los trabajadores y pobladores de las oficinas salitreras y centros mineros, así como con las luchas obreras:

\author{
Junto a mis pasos, muchos días \\ (o siglos) (o simplemente meses \\ de cobre, piedra y piedra y piedra, \\ es decir, de infierno en el tiempo: \\ de infinito sostenido \\ por una mano sulfurosa), \\ iban otras manos y pies \\ que sólo el cobre conocía. \\ Era una multitud grasienta, \\ hambre y harapo, soledades, \\ la que cavaba el socavón (267)
}

Ahora, los seres humanos adquieren rasgos del desierto: "abrasadas manos", "rudas manos ardientes", "pobre sangre despeñada", "sudor caído en el polvo", "pobreza abrasadora", "un hombre hecho de su misma arena. . . Su ancha compostura cubría, / como la arena numerosa" (274); "Juan Ovalle. . mano de piedra, mano de pared y de sequía" (489). De pronto, a los ojos del poeta testigo, el sacrificio de los mineros adquiere rasgos y prestigio míticos:

Yo he visto arder en la noche eterna

de Chuquicamata, en la altura,

el fuego de los sacrificios,

la crepitación desbordante

del cíclope que devoraba

la mano, el peso, la criatura

de los chilenos, enrollándolos

bajo sus vértebras de cobre,

vaciándoles la sangre tibia,

triturando los esqueletos

y escupiéndolos en los montes

de los desiertos desolados ${ }^{7}$ (333-4)

7 En el siguiente ejemplo, el poeta juega con el nombre de la Compañía Minera Norteamericana, Anaconda: "la tierra se traga un desfile / de hombres minúsculos que bajan / a las mandíbulas del cráter. . . la gran serpiente se los come, / los disminuye, los tritura, / los cubre de baba maligna, / los arroja por los caminos, / los mata con la policía, / los hace pudrir en Pisagua, / los encarcela, los escupe. .." (Canto General 334). 
Con la Guerra del Pacífico y la posterior crisis del salitre y su secuela de masacres obreras, el desierto añade a su faz terrible, el rol de escenario de muertes épicas y trágicas: Plaza Colón de Antofagasta, Santa María de Iquique, ${ }^{8}$ San Gregorio, Marusia,9 La Coruña, Pisagua, Chacabuco... Todavía, pues, otro elemento ominoso viene a cargar al desierto con un oscuro prestigio, en tanto espacio destinado a convertirse en campo de prisioneros políticos y de "detenidos desaparecidos".10 Neruda evoca, jugando con el nombre de la Compañía Minera Norteamericana, Anaconda:

la tierra se traga un desfile de hombres minúsculos que bajan a las mandíbulas del cráter. . . la gran serpiente se los come, los disminuye, los tritura, los cubre de baba maligna, los arroja por los caminos, los mata con la policía, los hace pudrir en Pisagua, los encarcela, los escupe. . . (334)

Asimismo, en la escritura poética de Raúl Zurita, el desierto de Atacama deviene símbolo de la condición sufriente y lacerada de Chile, como cuerpo maltratado y herido por la dictadura militar (INRI, 2004). En Purgatorio (1979), el desierto es 'espejismo', 'desierto maldito', 'estéril', 'puras manchas'; pero también 'auras', 'inri', 'mente', 'infinito', 'digno'. Pareciera que de pronto el desierto deviene imagen de lo incorruptible, últimas reservas de lo sagrado:

Miremos nuestra soledad en el desierto

Para que desolado frente a estas fachas el paisaje devenga

una cruz extendida sobre Chile y la soledad de mi facha

vea entonces el redimirse de las otras fachas: Mi propia Redención en el Desierto. (36)

8 Cf., mi artículo (en colaboración), "Santa María en la literatura: desde los versos populares hasta Rivera Letelier", citado en la bibliografía.

9 Las matanzas de Santa María y Marusia han sido noveladas, respectivamente, por Hernán Rivera Letelier (Santa María de las flores negras (2002) y Patricio Manns (Actas de Marusia (1993)).

10 Primer gobierno de Carlos Ibáñez (1927-1931), gobierno de González Videla (1947-1952) y Dictadura Militar (1973-1989). 
En el poema "El desierto", de INRI, en cambio, tal espacio es la imagen, el escenario y la voz de los sacrificados, por eso:

El desierto grita. Hay un muro de cal con nombres. Hay un muro blanco y pequeñas botellas con flores de plástico que gritan al doblarse bajo el viento Hay un barco en medio del desierto. Un barco reclinado sobre las piedras del desierto y arriba la losa a pique del cielo. El océano invertido del cielo cae sobre las piedras y éstas gritan. Nadie, salvo las piedras son capaces de gritar así. Mireya se tapa los oídos para no oír el chillido del desierto. Chile grita, el desierto de Chile grita. Mireya acumula pequeñas flores de plástico frente a un barco arrumbado en el pedrerío (...). Dice que el barco es Chile, que una vez fue un barco de vivos, pero que ahora surca el mar de piedras con sus hijos muertos (42-51)

\section{6}

En el ámbito de la novela, podemos distinguir la visión naturalista, entre 1900 y 1930, aproximadamente, con su perspectiva determinista (que alude a la cultura pampina en su período de vigencia, contradictoria, conflictiva, dolorosa (v. gr.: Tarapacá, de López y Polo (1903), Carnalavaca (1932), de Andrés Garafulic, Jaibón (1932), de David Rojas González, Tamarugal (1944), de Eduardo Barrios, La pampa trágica (1921) y Palomita brava (1923) de Víctor Domingo Silva). Aquí, el pampino de los inicios, en su mayoría migrante 'enganchado' desde el sur del país, muestra un permanente desarraigo y desasosiego por volver a sus paisajes y lares nativos. Con el tiempo, los deseos de regreso se tornan en amarga desesperanza, en resignación, es esfuerzo estoico por endurecer la piel y el ánimo. Así, en "El taita de la oficina", relato de Pezoa Véliz:

Llegó a la pampa hace muchos años. . .

Las había echado al norte por unos cuantos meses no más; quería juntar unos 'cobrecitos', comprar 'un peazo e tierra pa tener en que caerse muerto' y llevar donde el cura de Nancagua a la morena colorá que palabrió en la trilla de don Bacho Reyes. . . (21)

El punto de mira neorrealista (1940-1970 más o menos) asume la crisis de esa sociedad y adopta una mirada cronística, histórica e incluso legendaria (v. gr: Norte 
Grande (1944), de Andrés Sabella, Caliche (1954) y Los pampinos (1956), de Luis González Zenteno, los cuentos y novelas cortas de Mario Bahamonde ${ }^{11}$ o Hijo del salitre (1952)12 de Volodia Teitelboim). Ahora se asume una visión distinta, más comprensiva de los procesos transformativos que va experimentando la oficina y la complejización de su vida social. Para los campesinos migrantes, lo que partió siendo una situación transitoria, un sacrificio útil que les permitiría volver a su tierra, acabó siendo una opción definitiva: formaron familias, llegaron los hijos, nacidos en la pampa, enterraron a sus deudos. Vieron crecer el pueblo, se organizaron en mancomunales y filarmónicas, tuvieron escuelas, iglesias, mercados (pulperías), sus cantinas (pensiones o posadas), sus cines; experimentaron el reemplazo de la tecnología, el fin de las faenas y el cierre de muchas oficinas, así como la apertura de otras tantas; en fin, crearon formas de vida que los identificaron como pampinos. Así narra Teitelboim el proceso de aquerenciamiento de su protagonista en Hijo del salitre:

¡Ah! Cuando tocó de nuevo la pampa familiar, el yermo quemante bajo el sol eterno, se hubiera puesto a entonar un canto de triunfo, como si celebrara la reconquista del paraíso. . " "Contempló la pampa por la ventanilla. Halló hermoso el desierto. Probablemente se había hecho nortino, pampino de alma. Tal vez el niño de Salamanca — florida y subtropical— se tornaba poco a poco hombre del páramo, hasta la médula de los huesos" (82)

Y, con una pincelada, Sabella alude a la transformación física de un chilote en la pampa:

La pampa le concedió a Tito Soto una fisonomía de más; a su primitiva de varón del Archipiélago, hablase adherido esta otra: de siervo de la puna (90)

El relato contemporáneo (a partir de los años 90) añora y mitifica (v.gr.: las novelas de Hernán Rivera Letelier, Patricio Jara, Rodrigo Ramos, entre los mejores). En todos ellos se va construyendo un imaginario que supone ciertos núcleos de sentido que los vinculan y les otorgan su especificidad. Por ejemplo, Carlos Franz, en El desierto, escenifica el drama en que se ve envuelta una joven jueza en un campo de prisioneros que se instala en 1973, en un pueblo pampino. Ya el inicio del relato nos sitúa en una atmósfera asfixiante:

11 Sobre la narrativa de Mario Bahamonde, véase el documentado estudio de Maya 1998.

12 Sobre Hijo del salitre, véase: Marinello 1959: 45-56; Moretic 1962: 74-77; Bravo Elizondo y Guerrero Jiménez 2000: 22-23. 
Lo primero que Laura reconoció, al adentrarse en la vasta llanura desértica que rodeaba al oasis de Pampa Hundida, fue el horizonte de aire líquido. La muralla del espejismo temblaba en el horizonte del desierto, atravesando la autopista: una catarata de aire hirviente manando del cielo quemado por el reflejo de los salares, cayendo sobre el lecho del mar que se había ausentado un millón de años antes. Por un instante, tras ese muro de calor que palpitaba como un cristal recién fraguado, Laura creyó ver enormes rostros, siluetas humanas gigantescas, bocas distorsionadas, que gritaban en su dirección, que apelaban a ella, pidiéndole o enrostrándole algo inaudible, el dolor de una deserción tan larga como el millón de años transcurrido desde que el mar se evaporó de esas pampas. Era como si el propio paredón del horizonte líquido le aullara. (5)

La mirada de Rivera Letelier, ${ }^{13}$ en cambio, corresponde a quien contempla el mundo pampino desde las ruinas de sus pueblos fantasmas, en un porfiado esfuerzo por sobrevivir, como aquellas sociedades y cofradías de antiguos pampinos, que en los puertos aledaños tratan de repetir los ritos de una cultura ya desaparecida. La Reina Isabel cantaba rancheras (1994) es una verdadera elegía a la vida triste y dolorosa, no obstante, entrañable, de las oficinas en decadencia; Himno del ángel parado en una pata (1996) es la añoranza de la niñez pampina; a su vez, Fatamorgana de amor con banda de música (1998) recrea nostálgicamente la vida 'alegre' del único pueblo libre del desierto salitrero: Pampa Unión. Y Los trenes se van al purgatorio (2000) es una impresionante metáfora del retorno imposible, del gran espejismo que oculta la certeza de la muerte inevitable:

... a ambos lados de la línea férrea comienzan a dibujarse los cascotes de algunas oficinas salitreras abandonadas. Junto a sus ruinas, como flotando a la deriva en la reverberación de las arenas candentes, ondulan sus viejos cementerios de tumbas abiertas. . Y mientras su corazón en delirio es perforado por el silbato del tren alejándose, prosiguiendo su irreal itinerario por las ciento cuarenta y dos estaciones espectrales, sus ojos dolorosos miran desvanecerse en el aire, en la ardua luz de la pampa, la silueta transparente, ilusoria, melancólica, del último vagón (169 y 191).

\section{7}

Uno de los elementos fundamentales de la cultura pampina y nortina, en general, lo constituye, como queda dicho, el ámbito físico: el desierto, los cerros, el sol, el viento, las huellas, las piedras, el caliche, la tierra, el polvo, la noche pampina, la

13 Ver Ostria González 2005. 
camanchaca. Otro núcleo semántico importante se relaciona con el hombre pampino, sus rasgos físicos y síquicos, las relaciones laborales, los oficios, el espíritu solidario, el carácter reservado, su estoicismo, la atracción por la aventura, etc. Un tercer campo semántico se vincula al prostíbulo y a la cantina. Hay todavía otros tópicos importantes: la lucha social y las matanzas obreras; las creencias religiosas y supersticiones, los vínculos amorosos y familiares; las relaciones entre el pampino y el habitante de los puertos o de la precordillera, etc. De especial significación es la inventiva, apoyada en fantasmagorías, alucinaciones, espejismos, relatos de aparecidos o de extraviados. Al respecto, fantasea Salvador Reyes:

Imaginativo también es este personaje a quien los espejismos le abren con frecuencia sus extravagantes decorados. Al atravesar el páramo, al bordear el solar cegador de blancura, aparece la fantasmagoría de torres, de animales, de calles resplandecientes. Pero estas flotantes alucinaciones no son las únicas hechicerías del desierto: la naturaleza misma se rebela contra la realidad y esculpe en la piedra sus inesperadas creaciones. En la pared de la quebrada, vemos la casa de estilo barroco, sus historiadas columnas y sus balcones señoriales; más allá pasamos revista a una larga fila de elefantes; en lo alto del cerro la enorme cabeza de un viejo nos observa con sus ojos profundos; la reverberación del sol hace temblar su larga barba; al trepar una cuesta, las amenazadoras fauces de un cocodrilo nos obligan a dar un paso atrás (259).

\section{8}

Pero en el desierto de Atacama hay vida, de verdad, no solo la de microorganismos, descubiertos recientemente por científicos, más allá de la tierra. El desierto vive y es dador de vida: lo cruzan ríos y vertientes, napas subterráneas y géiseres; allí la camanchaca deja su huella húmeda todas las noches; allí crecen hierbas, plantas, árboles como la añañuca y la oreja de zorro, el chañar, el espino, el pimiento, el algarrobo, el tamarugo; allí se da el fenómeno sorprendente y hermoso del desierto florido; allí viven, junto a los seres humanos, la chinchilla, la llama, la alpaca, la vicuña, el zorro, varios tipos de ratones, lagartos; el flamenco, el jote, el pelícano, entre muchos otros. En suma, allí también vive la tierra, aunque con un frágil equilibrio, con intensidad y energía únicas. Lamentablemente, los últimos cincuenta años, la minería ha acaparado todas las fuentes de agua y, en consecuencia, ha hecho languidecer el frágil equilibrio ecológico del desierto. ${ }^{14}$ Mas, los poetas y narradores del Norte han sabido descubrir esa vida, precaria pero intensa, que transforma y enajena, que enamora y empampa, haciéndose una con los sujetos que la cantan y la cuentan.

14 Cf. Marquet (1978) y Núñez (1992), (1995), (2002). 
Nicolás Ferraro nació en Pampa Unión y la pampa lo marcó para siempre. A través de sus relatos y poemas, pone en relación un conjunto de rasgos que permiten vislumbrar, sin grandes estridencias, pero con verdad estética y antropológica, una visión convincente, persuasiva y conmovedora del habitante del norte, especialmente, de la pampa y de la puna. Desde la naturalidad de los gestos cotidianos hasta la evocación mítica y legendaria del indio atacameño, la escritura de Ferraro se construye como un continuo gesto de adhesión a los ancestros en medio de un hábitat desolado y triste, pero cargado de querencias. Mientras sus versos resuman amor raigal y adhesión incondicional por su desierto, al que le atribuye los poderes del agua:

Tierra mía de espanto, triste, inerme; océano de fuego, mar de arena; he de volver hasta tu seca vena para reverdecerme (Tierramor 21)

Sus relatos, a su vez, trasmiten imágenes persuasivas de la agonía y muerte de los pueblos salitreros, con los que, sin duda, el narrador se siente involucrado:

cerrando los ojos para evitar la resolana uno puede percibir. . . algunos muros derruidos donde el viejo viento se estrelló llorando. El aire caliente da un aspecto terrible a lo que ya es terrible y solo. Deforma las perspectivas. Brilla todo con furia. Hay espejismos; lagos de agua pura y helada, castillos, embarcaciones y muchachas, ciudades. Enloquecemos bajo el sol amarillo e implacable. (Terral 12)

Finalmente, el hablante de su poemario Canto al indio atacameño (1996) asume sobre sí la condición de indígena: viviendo y reviviendo los sufrimientos de su pueblo y de su tierra, su oikos, se identifica con ellos y su devenir:

Eres quien soy y soy quien eres...

y el tiempo. . . no puede ya borrarte de mí mismo

no puede ya alejarme de tu rostro (44)

Aunque ya nada exista, no deja de persistir el canto doliente que lo une a su tierra más, allá de la muerte: “Todo aquello que fue, que nos pasó y hoy está muerto y llora" (Tierramor 12).

Mario Bahamonde, nacido en Taltal y avecindado en Antofagasta, ha interiorizado e imaginado de modo entrañable las vivencias surgidas de ese diálogo infinito entre el hombre y la tierra; en su caso, diálogo signado por la soledad. En uno de 
sus mejores cuentos, "Soledad en la puna", de Derroteros y Cangalla (1978), escribe: "Resulta difícil concebir otro lugar en esta parte de América donde la soledad apriete con dientes más agudos en la carne aventurera" (241), y describe a sus personajes como "sombras perdidas, infinitamente pequeñas, en medio de una soledad tan vasta como toda la tierra" (243). El protagonista indígena del cuento encarna la supervivencia de los antiguos ritos andinos: "Padre Apacheta, aquí te traigo estas hojas de coca y estas lanas teñidas porque con ellas se alivia y se abriga la vida que tú nos das en estas alturas. Ayúdame también en mis andanzas". Y añade:

A Condorumi todo lo identificaba con la cordillera. Su quemada piel morena, tostada por el viento cordillerano. Sus anchas narices indígenas, deformadas por la falta de oxígeno en las cumbres. Y su mentalidad primitiva, apegada a la tierra y a sus creencias. . Su verdadero amor era la cordillera. . . Sentía la cordillera en su destino. . . en cuyas montañas respiraba un aire de libertad y de misterio mientras el silencio de la soledad le apretaba las distancias, entre cañadones o entre los desfiladeros abismales (243-50).

Y concluye en la fusión ecológica:

Para él esas montañas, esos cañadones metidos entre las cumbres, esos desfiladeros que se despeñaban de cabeza hacia el abismo, las nevazones despiadadas que solían congelar la existencia y el aire puro y ralo, todo eso junto era el amasijo donde se fundía el hombre con la piedra, la existencia con la naturaleza. (245-6)

El protagonista de otro de sus cuentos, "Desierto", se ensimisma en la soledad de la montaña, hasta oír la voz de la tierra que cuenta su historia:

Uno piensa en la distancia y ocurre que está ahí, pero como si tuviera la piel muerta. Nada es sencillamente más impresionante que esta soledad seca y apretada sobre la piedra y la tierra. Suele pasar un vientecillo tenue que cría alas hasta convertirse en bocanadas cálidas atropellando los andurriales del desierto. Y sobre la piel geológica se elevan columnas enormes de un terral arremolinado por la furia. Esto es todo en medio de esa soledad, salvo un murmullo muy leve, la voz del viento, quizás o la voz del desierto que pasa cantando su largo historial, dormido entre sus grietas!. . . Porque siempre la tierra aquí ha ejercido su dominio sobre el hombre. (291)

Tal vez por eso, el desierto deslumbra y atrae. A través de otro de sus personajes, Bahamonde, se unimisma con el paisaje, definitivamente empampado, descubre la vida del desierto en una especie de epifanía ecológica: 
Todo ese paisaje era como si los ojos se llenaran de una extraña y confusa felicidad. . . yo estaba dentro del paisaje, mirando con veneración el cuerpo pétreo de las montañas. . Yo sabía desde antes que todo está vivo. Los cerros, el viento, todo está vivo y permanece vivo en medio de sus misterios y de sus designios. Lo sé tan bien como sé igualmente que yo no soy un hombre de ciencia. Y si ahora ando en medio de esta soledad es porque también sé que hay algo más que permanece vivo. Y ese algo es el esplendor de la belleza de la tierra, que por estas cumbres se conserva más pura desde tiempos inmemoriales. (184)

Finalmente, Andrés Sabella, antofagastino, de padre palestino, no solo es el poeta del Norte Grande porque inventó su nombre, sino porque tuvo la sensibilidad de descubrir la vida del desierto, de las piedras y las arenas, del viento y del cielo:

Aquí la tierra vive dentro de su propia sombra; vive en equilibrio de inmensidad. . . Es la tierra donde la piedra habla a las piedras, donde un coro de piedras da de sí hasta el infinito. // Despertando la desolación de las arenas, rozando el hombro de los quiscos, el viento vuela con el cielo a su espalda. . . // Un día la sed soñó un juguete: nació el espejismo. (Hombre de cuatro rumbos 119)

En Hombre de cuatro rumbos, Sabella es capaz de intuir la realidad de la pampa en toda su complejidad ecológica. Su semántica de muerte y vida integra una dinámica cósmica, que supera la visión negativa dominante en la literatura chilena: "Al pie de este sol: semillería de piedras, colores que envenenan, muerte. ¡He aquí la fotografía de la pampa chilena! Y, sin embargo, allí ha sido - y es — la vida el acento dominador" (13). Más aún, Sabella se reconoce hijo de la piedra, a la que canta con auténtico amor filial:

¡La piedra! Yo quiero cantar la piedra:

¡Oh madre oscura, mía, repartida!

Cuando mi amor la toma y acaricia, en la mano me queda, pura y tibia, la forma temblorosa de la Tierra. .

Y entonces, la piedra (metonimia del desierto), se hace fecunda, se ecologiza como "una fruta plena de semillas":

Levadura de rabias y osamentas.

La piedra en cuajos, como fruta seca, 
O en multitud de inmóvil fantasía,

Recuerda al hombre su raíz marchita:

¡ella - la piedra - mendicante o cima,

Siempre es un más allá de sementeras! (58)

Es, pues, el desierto sabelliano, un desierto vivo, fecundo, capaz de contener a todos los seres, de ser todos los seres, poético anticipo de lo que postula la astrofísica actual, respecto del origen del ser humano y el universo. Por eso, la pampa —el desierto condensado en la piedra - es cantada como "flor dormida en su tristeza", “espuma”, "sonrisa", "harina” y "levadura”, "fruta”, "fantasía”, “raíz”, imágenes todas que trascienden sus atributos negativos (sequedad, esterilidad, gravedad, inmovilidad, muerte) y que se resumen en ese "un más allá de sementeras!", que culmina en la confidencia del poeta: "Yo he visto temblar el horizonte de la pampa, como el límite mismo de la vida" (39).

Sabella no solo se unimisma con la pampa y el mar, con los cerros y el sol; también canta al hombre del Norte, el pionero, el cateador, el chango, el "chichero", el tatuador y el pescador; el obrero, el pampino y el "empampado", otro término de invención sabelliana para aludir no al forastero extraviado, sino al embrujado por la pampa, atrapado en su laberinto de arenas y camanchaca o alucinado por visiones fantásticas o promesas de aventuras. Desfilan por sus versos las fantasmales oficinas salitreras, los mágicos puertos, los pueblos atacameños y sus reliquias ancestrales, los cerros grises, florecidos por la luz crepuscular, los quiscos y pimientos solitarios, los viejos muelles y los pájaros marinos, en fin, el mar y la pampa interminables. Recuérdese, por último, su ya clásica estampa del estoico pimiento, figura del minero empampado, síntesis perfecta de la vida del desierto:

El pimiento no es un árbol. Para crecer, generoso y solo, en la desgarradora infelicidad de la pampa, se precisa haber sido, antes que árbol, un minero. . . Allí, verdea el pimiento, como un padre de soles. Pastor de la distancia. . . Se le ve desde lejos. Y uno no podría as egurar que esa sombra que se yergue remota sea un árbol, o un ser que decidió su suerte en amor de brasas y espejismos. (Norte Grande 99)

En suma, lejos de ser la negación de todo lo viviente, el espacio negativo por excelencia, el desierto, a pesar de su ruda apariencia, de sus extremosos calores y fríos y de lo mal que ha sido tratado por los seres humanos que lo han explotado los últimos quinientos años, sigue siendo un lugar, donde la vida ha sido posible y lo sigue siendo. Así lo atestigua la palabra de poetas y narradores del Norte que, a través de poderosas intuiciones, son capaces de percibir la belleza profunda de la tierra, su fuerza vital, su energía creadora. Poetas y narradores que llegan a identi- 
ficarse amorosamente con ella y a asumir su voz, como hijos de una madre dura, pero al fin aquerenciadora:

Al principio el paisaje nos golpeó tan crudamente el alma, que nos habíamos sentido trasplantados a las sequedades sulfurosas de un planeta ajeno. Sin embargo, poco a poco habíamos venido aprendiendo a querer estos páramos miserables, a mirar y admirar su áspera belleza de mundo a medio cocer. Habíamos ido descubriendo su alma oculta, como el tornasolado color mineral de los cerros, por ejemplo; o la diafanidad prodigiosa de sus cielos nocturnos, siempre ahítos de estrellas y de luminosidades misteriosas. O como este crepúsculo teñido de arreboles que ahora mismo teníamos frente a nosotros y que era como si el sol hubiese estallado en una explosión cósmica justo al llegar a la raya del horizonte. (Rivera Letelier, Santa María de las flores negras 50) 
CARTOGRAFíAS E IMAGINARIOS DE LA LITERATURA CHILENA: ESPACIOS, TEMPORALIDADES Y SUJETOS

\section{Obras citadas}

Bahamonde, Mario. Derroteros y Cangalla. Santiago: Nascimento, 1978.

Ferraro, Nicolás. Terral. Santiago: Alerce, 1959.

. Tierramor. Antofagasta: Instituto de Investigaciones Antropológicas, Facultad de Educación y Ciencias Humanas, Universidad de Antofagasta, 1983.

. Canto alindio atacameño. Antofagasta: Instituto de Investigaciones Antropológicas, Facultad de Educación y Ciencias Humanas, Universidad de Antofagasta, 1996.

Franz, Carlos. El desierto, Buenos Aires: Sudamericana, 2005.

Maya Cortés, Osvaldo. Mario Bahamonde, novelista: Literatura y Conciencia Histórica del Norte Chileno. Antofagasta, Universidad Católica del Norte, 1998.

Marquet, Pablo et al. "Los ecosistemas del Desierto de Atacama y área andina adyacente en el norte de Chile". Revista Chilena de Historia Natural 71 (1978): 593-617.

Mistral, Gabriela. Gabriela anda por el mundo. Santiago: Andrés Bello, 1978.

Mariño de Lobera, Pedro. Crónica del Reino de Chile (1551). Santiago: Universitaria, 1960.

Neruda, Pablo. Confieso que he vivido. Madrid: Millenium, 1999.

__. Canto General. Edición de Enrico Mario Santí. Madrid: Cátedra, 2003.

Núñez, Lautaro. Cultura y conflicto en los oasis de San Pedro de Atacama. Santiago: Universitaria, 1992.

. "Evolución de la ocupación y organización del espacio atacameño". Pierre Pourrut et al. (eds.), Agua, ocupación del espacio y economía campesina en la región atacameña. Aspectos dinámicos. Antofagasta: Universidad Católica del Norte, 1995. 18-60.

. "Breve Historia de los Pueblos Atacameños". Documento de Trabajo 59 (2002). Comisión Verdad Histórica y Nuevo Trato. San Pedro de Atacama.

Ostria González, Mauricio. "Visión nerudiana del desierto nortino". Revista Chilena de Literatura 65 (2004): 111-121.

. “La identidad pampina en Rivera Letelier". Acta Literaria 30 (67-79): 2005.

. "Santa María en la literatura: desde los versos populares hasta Rivera Letelier". Revista Chilena de Literatura 75 (2009): 271-293. 
_ _ "Notas sobre la imaginación material en la poesía chilena". El laberinto y el hilo. Homenaje a Gilberto Triviños. Eds. E. Faúndez y O. Lermanda. Concepción: U. de Concepción, 2012. 139-147.

Pezoa Veliz, Carlos. "El 'Taita' de la oficina". Antología de cuentos y relatos mineros de Chile. Ed. Javier Jofré Rodríguez. Chile: Ediciones Universitarias de Valparaíso, 2015.

Reyes, Salvador. Andanzas por el desierto de Atacama. Antofagasta: Editorial Portada, 1963.

Rivera Letelier, Hernán. Los trenes se van al purgatorio. Santiago: Planeta, 5ª 2000. Santa María de las flores negras. Buenos Aires, Seix Barral, 2002.

Sabella, Andrés. Norte Grande. Santiago: Orbe, $3^{a}$ ed. definitiva, 1966.

_.. Hombre de cuatro rumbos. Antología del Norte Grande. Santiago: Nascimento, 1978.

Teitelboim, Volodia. Hijo del salitre. Santiago: LOM ediciones, 2002.

Zurita, Raúl. Purgatorio. Santiago: Fondo de Cultura Económica, 2003. . INRI, México/Santiago: Fondo de Cultura Económica, 2004. 